\title{
The Internet as Information \\ and Communication Environment, Instrument of Legal Communication and Object of Legal Regulation
}

\author{
Roman A. Romashov ${ }^{\text {a }}$ \\ and Vladislav Iu. Panchenko ${ }^{\mathrm{b} *}$ \\ ${ }^{a}$ Saint-Petersburg University \\ of the Humanities and Social Sciences \\ 15 Fuchika Str., Saint-Petersburg, 192236, Russia \\ ${ }^{b}$ Siberian Federal University \\ 79 Svobodny, Krasnoyarsk, 660041, Russia
}

Received 11.02.2016, received in revised form 01.03.2017, accepted 24.03.2017

The article analyzes the impact of the Internet on the traditional understanding of legal regulation and state sovereignty. The authors come to conclusions that the cyberspace is a self-regulatory system with its own parameters of internal and external interactions, which a state has no power to subdue or fully control. Creation and wide implementation of virtual institutions causes a qualitative reevaluation of approaches to the form, content and subjects of social relations. In particular, the liability of the Internet providers has become an urgent challenge for legal theory and practice. Legal acknowledgement of cybercrimes and cyberterrorism offences is considered to be a positive move forward. However, the article outlines that the states still have not developed any common policy in this field. The authors argue that emergence of the cyberspace has replaced the principle of hierarchy with the principle of horizontal interaction, which guarantees the equality of all parties to the Internet relations.

Keywords: cyberspace, the Internet provider, virtual law, cybercrime, self-regulation, state sovereignty, legal regime.

The article was prepared with the support of the Russian Humanitarian Scientific Foundation. Project No. 15-33-01354.

DOI: 10.17516/1997-1370-0066.

Research area: philosophy, law.

\section{Introduction}

Nowadays the modern world witnesses a transitional state of social relations, where virtual law and its principles, that govern relations in the sphere of intangible legal reality, are becoming more important and influential. The Internet plays the roles of the information and communications environment, the instrument

(C) Siberian Federal University. All rights reserved

* Corresponding author E-mail address: romashov_tgp@mail.ru; panchenkovlad@mail.ru 
of legal communication and the object of legal regulation.

From the perspective of theoretic and applied studies, the Internet is described as a social and legal phenomenon, which cannot be effectively understood and analyzed without in-depth research into national and cultural traditions of a particular society in the context of a concrete time and territorial framework.

When the Internet is approached as a specific social and technical system providing an opportunity for a remote communication between persons, it reveals many related legal issues. The most challenging ones include the problems connected to determination of court that has jurisdiction over cases on the grounds of the Internet relations, liability of the Internet providers (intermediaries) as well as development and implementation of initiatives in respect of self-regulation on the Internet (Naumov, 2002).

\section{Influence of the Internet on Legal Regulation and Sovereignty}

Currently a noticeable decrease in social and political significance of the state and state sovereignty is taking place. Between the $19^{\text {th }}$ and $20^{\text {th }}$ centuries, a national state was considered to be a closed administrative and territorial entity, which strictly controlled all activities within its borders (including information interactions) through its numerous governmental agencies and bureaucracy. Since the latter half of the $20^{\text {th }}$ century, the "information explosion" has been destroying the boundaries, which restricted flows of information, and establishing a supranational information environment as a basis for more active and various communications at different levels of human society (Land, 2013). Therefore, now the Internet is becoming a key instrument of communication.
TheInternetasacommunicationenvironment is not only a construction guaranteeing an "information service", but also a self-regulatory system with its own parameters of internal and external interactions. The state may affect the Internet relations in different ways. However, it has no power to influence either such relations or their participants (representatives of the Internet society). In other words, the state cannot abolish or subdue them to make the cyberspace and cyber technologies a foreseeable and controllable mechanism for manipulation of thoughts and behavior of masses.

Concerning the liability of the Internet providers, it is vital to emphasize that the traditional criteria of ownership and possession are not applicable within virtual law and the Internet environment (Wauters, Lievens, Valcke, 2014; Weber, Struder, 2016). Conventionally property rights predetermine possession, use and disposal of material objects. Creation and wide implementation of virtual institutions (such as surplus value, intellectual property, information communications) causes a qualitative reevaluation of approaches to the form, content and subjects of social relations. Providers of the Internet communication stay in touch with each other wherever they are located around the globe. Meanwhile, such providers (natural or legal persons) may not even have full legal capacity. Furthermore, sometimes providers belong to organized criminal groups (Boeviki IGIL, 2014), while states continue blaming each other for support of cyberterrorism through government intelligence services.

Countermeasures against cyberterrorism have become an important sphere of international cooperation. The United Nations and its specialized agencies passed a range of international acts concerning different aspects of cyberterrorism prevention. In addition, the Council of Europe adopted the Convention 
on Cybercrime in 2001, which was signed by the USA and Japan as well. The Convention determines the list of offences in the sphere of information technologies, committed against the computer data or by misuse of devices. According to the Convention, each party to it shall adopt such legislative measures as may be necessary to empower its competent authorities to perform the following procedures for the purpose of specific criminal investigation of cybercrimes: seize or similarly secure a computer system or a part of it, or a computer-data storage medium; make and retain a copy of those computer data; maintain the integrity of the relevant stored computer data; render inaccessible or remove those computer data in the accessed computer system. The Convention also requires to adopt legislative measures to compel a service provider to collect or record content data through the application of technical means and to co-operate and assist the competent authorities in the collection or recording of content data in real-time transmitted by means of a computer system (Kiberterrorizm, 2015). Moreover, it is recommended to oblige a service provider to keep confidential the fact of such co-operation.

From 2001 to 2005, Russia actively participated in drafting of a project for the Council of Europe Convention on the Prevention of Terrorism and was the first state to ratify it on 21 April 2006. This Convention for the first time in history internationally established as criminal offences provocation to commit a terrorist offence, recruitment and training for terrorism (Kiberterrorizm, 2015).

Legal acknowledgement of cybercrimes and cyberterrorism offences is a positive move forward (Strikewerda, 2014). However, the states still have not developed any common policy to resist the abovementioned forms of information and legal deviation, which substantially complicates the creation of a highly effective mechanism to impose liability upon those service providers who are involved in criminal activities.

\section{Self-Regulation within the Cyberspace}

Many problems arise from the creation and implementation of initiatives in the sphere of self-regulation within the cyberspace. It is crucial to understand the peculiarities of correlation and mutual influence of institutions, which perform administrative regulation or corporate self-regulation functions, in order to solve the abovenamed issue. Following this approach, the problem of correlation between public and private law turns out to be actual as well. A state is traditionally recognized as the "center of publicity" that has an authority over everyone, who lives or stays within its jurisdiction. At the same time, self-organized and self-regulatory bodies are independent to the extent that a state allows them to be. As a result, private law is considered to be an element of public law, while the scope of individual rights and freedoms completely depends on the sovereign discretion.

In contrast, creation of a cyberspace means a qualitative change in the concept of governmental management. The principle of hierarchy has been replaced by the principle of horizontal interaction, which guarantees a real equality of subjects in the Internet relations, except for their technical capabilities and national or cultural features of mentality.

\section{Conclusion}

All in all, the Internet can be described as the information and communications environment, the instrument of communication and the object of legal regulation. The Internet is a supranational information and legal entity, which is organized and functions in accordance with norms and principles that are completely different from hierarchy, typical for the state governance. 


\title{
References
}

Boeviki IGIL opublikovali v internete video kazni amerikanskogo zhurnalista (2014) [ISIS Group Shared the Video of American Journalist's Execution on the Internet]. Available at: http://xitfilms. ru/kino/Боевики ИГИЛ опубликовали в интернете видео казни американского журналиста (accessed 1 February 2017).

Kiberterrorizm: ugroza natsional'noi i mezhdunarodnoi bezopasnosti (2015) [Cyberterrorism: a Threat to National and International Security]. Available at: http://www.studfiles.ru/preview/4645686/ (accessed 1 February 2017).

Land, M. (2013). Toward an International Law of the Internet, In Harvard International Law Journal, 54, 393-458.

Naumov, V.B. (2002). Pravo i Internet. Ocherki teorii i praktiki [Law and the Internet: Features of Theory and Practice]. Moscow, Knizhnyi dom "Universitet", 432 p.

Strikewerda, L. (2014). Should Virtual Cybercrime be Regulated by Means of Criminal Law? A Philosophical, Legal-Economic, Pragmatic and Constitutional Dimension, In Information \& Communications Technology Law, 23, 31-60.

Wauters, E., Lievens, E., Valcke, P. (2014). Towards a Better Protection of Social Media Users: a Legal Perspective on the Terms of Use of Social Networking Sites, In International Journal of Law and Information Technology, 22, 254-294.

Weber, R.H., Studer, E. (2016). Cybersecurity in the Internet of Things: Legal Aspects, In Computer Law \& Security Review, 32, 715-728.

\section{Интернет как информационно-}

коммуникативная среда,

инструмент правовой коммуникации

и объект правового регулирования

\author{
P.А. Ромашов ${ }^{\text {a }, \text { В.Ю. Панченко }}$ \\ ${ }^{a}$ Санкт-Петербургский гуманитарный \\ университет профсоюзов \\ Россия, 192236, Санкт-Петербург, ул. Фучика, 15 \\ ${ }^{\sigma}$ Сибирский федеральный университет \\ Россия, 660041, Красноярск, пр. Свободный, 79
}

\begin{abstract}
В статье исследуется влияние сети Интернет на традицонные представления о правовом регулировании и государственном суверенитете. Авторы приходят к выводам о том, что интернет-пространство представляет собой саморегулируемую систему, которая имеет свои параметры внутрисистемного и межсистемного взаимодействия. Создание и широкое использование виртуальных институтов обусловливает качественную переоченку подходов к пониманию формы, содержания и субъектов сочиальных отночений. В частности, одной из теоретико-прикладных проблем стал вопрос об ответственности интернет-провайдеров. Юридическая квалификачия киберпреступлений и кибертерроризма рассматривается как
\end{abstract}


позитивная тенденция, однако подчеркивается, что государства до сих пор не выработали единой политики в регулировании данной сферы общественных отнотений. По мнению авторов, появление интернет-пространства означает переход от приниипа иерархичности к приниипу сетевого взаимодействия, обеспечивающего реальное равенство субъектов интернетотночений.

Ключевые слова: интернет-пространство, интернет-провайдер, виртуальное право, киберпреступление, саморегулирование, государственный суверенитет, правовой режим.

Статья подготовлена при поддержке Российского гуманитарного научного фонда. Проект № 15-33-01354.

Научная спеииальность: 09.00.00 - философские науки, 12.00.00 - юридические науки. 